\title{
Strategi Pembelajaran Pendidikan Pancasila dan Pendidikan Kewarganegaraan sebagai Mata Kuliah Pembentuk Karakter Mahasiswa
}

\section{Learning Strategies for Pancasila Education and Citizenship Education as Courses Student Character Shaper}

\author{
Anif Istianah ${ }^{1}$, Sukron Mazid ${ }^{2}$, Rini Puji Susanti ${ }^{3}$ \\ Email: istianahanif88@gmail.com, sukronmazid@untidar.ac.id, \\ rinipuji.susanti@gmail.com \\ ${ }_{1}$ Program Studi PPKn, FKIP, Universitas Nusa Cendana \\ ${ }^{2}$ Program Studi Pendidikan Bahasa dan Sastra Indonesia, FKIP, Universitas Tidar \\ 3Program Studi PPKn, FKIP, Universitas Muhammadiyah Purwokerto
}

\section{INFORMASI ARTIKEL}

Diterima: 26 April 2021

Direvisi: 26 Juni

Publikasi Online: 30 Juni 2021

\section{KATA KUNCI}

Strategi Pembelajaran, Pendidikan Pancasila, Pendidikan

Kewarganegaraan, Pembentuk Karakter

\section{A B S T R A C T}

The study is done to see how Pancasila Education and Civic Education subject strategies as a college education compulsory in character building sublime Pancasila students based on personality. Background research is related to problems that occur in the country: anarchism, radikalisme, terrorism, and other. These problems can undermine the unity of the Republic of Indonesia. The research is in University and the University of Muhammadiyah Purwokerto Tidar Nusa Cendana. But this research is qualitative descriptive method which is through observation, interview, and documentation. The validity of data over (trianggulasi) sources and methods. Data and analysis is by reduction, presentation of data, and the withdrawal of the conclusions. The result showed that Pancasila Education and Civic Education as subject to common (MKWU) at the University and the University of Muhammadiyah Purwokerto Tidar Nusa Cendana. The Subject has the role so important in the development of personality students in accordance with nilai-nilai Pancasila. It is seen in cognitive learning: achievement, psychomotor, affective. In reaching cognitive, students are taught some material relating to the reality in civil with Pancasila values. The objective is to students having knowledge based on good Pancasila. The psychomotor focused on learning skills students by using the method as a form of learning based on the kids. An affective seen in character students so far in accordance with Pancasila values. 


\begin{abstract}
A B S T R A K
Penelitian ini dilakukan untuk mengetahui strategi mata kuliah Pendidikan Pancasila dan Pendidikan Kewarganegaraan sebagai mata kuliah wajib dalam membentuk karakter mahasiswa berdasarkan nilai-nilai luhur Pancasila. Latar belakang penelitian ini terkait dengan permasalahan yang terjadi di negeri ini: anarkisme, radikalisme, terorisme, dan lainnya. Permasalahan tersebut dapat merusak persatuan dan kesatuan Republik Indonesia. Tempat penelitian ini berada di Universitas Nusa Cendana, Universitas Tidar dan Universitas Muhammadiyah Purwokerto. Adapun metode penelitian ini adalah deskriptif kualitatif yakni melalui observasi, wawancara, dan dokumentasi. Keabsahan data melalui trianggulasi (sumber dan metode). Sedangkan Analisis yaitu dengan reduksi data, penyajian data, dan penarikan kesimpulan. Hasil penelitian menunjukkan bahwa mata kuliah Pendidikan Pancasila dan Pendidikan Kewarganegaraan sebagai Mata Kuliah Wajib Umum (MKWU) di Universitas Nusa Cendana, Universitas Tidar, dan Universitas Muhammadiyah Purwokerto. Mata kuliah ini memiliki peranan yang begitu penting dalam usaha pengembangan kepribadian mahasiswa yang sesuai dengan nilai-nilai Pancasila. Hal ini dapat dilihat pada hasil pencapaian pembelajaran yaitu kognitif, psikomotor, afektif. Pada pencapaian kognitif, mahasiswa diberikan materi yang berkaitan dengan realita yang terjadi di masyarakat dengan nilai-nilai Pancasila. Tujuannya adalah agar mahasiswa memiliki pengetahuan yang baik berlandaskan Pancasila. Pencapaian psikomotorik ditekankan pada keterampilan mahasiswa dengan menggunakan metode pembelajaran sebagai bentuk pembelajaran yang berpusat pada mahasiswa. Prestasi afektif terlihat pada karakter mahasiswa yang selama ini sesuai dengan nilai-nilai Pancasila.
\end{abstract}

(C) Heritage: Journal of Social Studies Institut Agama Islam Negeri Jember, Indonesia

https:// doi.org/ 10.xxxx/ xxxx

This is an open access article under the CC-BY-SA license

\title{
Pendahuluan
}

Pancasila sebagai dasar Negara Indonesia mengandung makna, bahwa nilai-nilai Pancasila yang terkandung di dalamnya menjadi dasar serta pedoman bagi bangsa Indonesia. Adapun nilai-nilai Pancasila adalah nilai filsafati yang menjadi dasar serta dijadikan sebagai peraturan dan dasar dari norma-norma yang berlaku di Indonesia. Tujuan Pendidikan Pancasila adalah membangun dan membentuk sikap maka pertamatama proses pendidikannya harus bisa menghadirkan penghayatan terhadap nilai-nilai Pancasila. Pancasila adalah dasar filsafat negara Indonesia, sebagaimana tercantum dalam Pembukaan UUD 1945. Oleh karena itu, setiap warga negara harus mempelajari, 
mendalami, menghayati serta mengamalkan dalam segala bidang kehidupan (Syarial Syarbaini, dkk., 2012: hal. 1).

Sedangkan nilai dasar utama Pancasila itu bersifat normatif dan abstrak yang dijadikan landasan dalam kegiatan berbangsa dan bernegara. Pancasila sendiri sebagai dasar negara berarti menjadi sebuah pedoman dalam penyelenggaraan segala tatanan serta norma-norma hukum dalam penyelenggarakannya. Pendidikan Kewarganegaraan (PKn) mempunyai tiga kompetensi yang terdiri dari kompetensi pengetahuan, kompetensi ketrampilan dan kompetensi sikap (civic knowledge, civic skill, and civic disposition) (Risti, dkk, 2018: hal. 126). Tentunya tiga kompetensi tersebut menjadi dasar dalam menjadikan serta membentuk para mahasiswa menuju good citizen.

Kompetensi lulusan Pendidikan Kewarganegaraan adalah seperangkat tindakan cerdas, penuh rasa tanggung jawab dari seorang warga negara dalam berhubungan dengan negara dan memecahkan berbagai masalah hidup bermasyarakat, berbangsa, dan bernegara dengan menerapkan konsepsi falsafah bangsa, Wawasan Nusantara dan Ketahann Nasional (Hamidah, 2019). Pendidikan Kewarganegaraan (PKn) menjadi salah satu mata pelajaran atau mata kuliah wajib dari jenjang sekolah dasar, menengah, atas sampai perguruan tinggi. Pendidikan Kewarganegaraan (PKn) tentunya harus mampu berkontribusi dan memberikan perhatian dalam pengembangan pengetahuan, nilai, akhlak, moral, dan sikap serta perilaku peserta didik/mahasiswa. Adapun misi dari PKn adalah turut mencerdaskan kehidupan bangsa dan negara. Sesungguhnya PKn adalah sebuah pembelajaran tentang kehidupan sehari-hari dalam bermasyarakat berbangsa dan bernegara. PKn juga mengajarkan bagaimana menjadi manusia yang baik, paripurna serta bertanggung jawab. PKn menuntut peserta didik menunjukkan sikap yang baik, kreatif, dan bertanggung jawab (Mazid \& Suharno, 2019). Menuju warga negara yang baik tentunya harus mampu menjunjung tinggi nilai-nilai Pancasila yang menjadi dasar negara Indonesia.

Mata kuliah PKn di Perguruan Tinggi sebagai keberlanjutan dari studi-studi dari SDSMA. PKn diajarkan di Perguruan Tinggi lebih luas, komprehensif serta detail sampai terperinci penjelasannya. Apalagi jika mengambil program studi PPKn, diharapkan lebih explore dari materinya. PKn diajarkan sampai tingkat Perguruan Tinggi ada dasarnya yaitu pada Pasal 37 ayat (1) dan (2). Kementerian Pendidikan dan Kebudayaan Indonesia (2003), tentang Sistem Pendidikan Nasional disebutkan bahwa PKn wajib dimuat dalam kurikulum pendidikan dasar, pendidikan menengah, dan pendidikan tinggi yang dimaksudkan untuk membentuk peserta didik menjadi manusia yang memiliki rasa kebangsaan dan cinta tanah air sesuai dengan Pancasila dan UUD 1945. 
Pasal 3 Keputusan Dirjen Dikti No. 43/Dikti/2006 tentang Rambu-rambu Pelaksanaan Mata Kuliah Pengembangan Kepribadian di Perguruan Tinggi, PKn menjadi salah satu kelompok Mata Kuliah Pengembangan Kepribadian (MPK) yang dirancang secara khusus untuk memberikan pemahaman dan pengertian kepada para mahasiswamahasiswa tentang pengetahuan dan kemampuan dasar yang berkenaan dengan hubungan antar warga negara serta pendidikan bela negara. PKn juga sebagai bekal agar menjadi warga negara yang mempuyai sikap nasionalisme yang dapat diandalkan oleh bangsa dan negara.

Selanjutnya memuat materi-materi mengenai hukum dan politik yang ada dan terus berkembang. Mahasiswa diajarkan untuk menjadi lebih bertanggung jawab, demokratis, analitis, kritis dan solutif terhadap masalah-masalah yang timbul baik di dalam negeri maupun luar negeri. Tidak hanya sebatas teori-teori saja yang diberikan kepada para peserta didik. Tetapi, juga memberikan penanaman values melalui sentuhan moral dan sikap sosial.

Berdasarkan Pasal 56 Undang-Undang Nomor 12 Tahun 2012 Tentang Pendidikan Tinggi, maka wajib mata kuliah Pendidikan Pancasila dan Pancasila Kewarganegaraan diselenggerakan di kampus, yang masing-masing merupakan entitas utuh psikopedagogis/andragogis (Kaelan \& Zubaidi, 2007). Oleh karena itu, Pendidikan Pancasila dan Pendidikan Kewarganegaran menjadi salah satu mata kuliah yang harus dan wajib diajarkan di seluruh perguruan tinggi di Indonesia.

Kehidupan dalam kampus merupakan awal dari pembentukan karakter jati diri seorang mahasiswa. Bagaimana seorang mahasiswa mengenal dirinya sendiri sebagai bagian dari lingkungan akademik sekaligus menjadi bagian dari masyarakat. Kampus-kampus di Indonesia mengusahakan kepada para mahasiswanya untuk berpegang teguh pada Norma dan Hukum yang berlaku di masyarakat maupun negara. Serta senantiasa mengamalkan Tri Dharma Perguruan Tinggi.

Tujuannya adalah untuk mencetak para generasi muda mempunyai akhlak, moral dan kritis dalam kehidupan bermasyarakat sebagai pegejewantahan tujuan pendidikan nasional. Untuk mendukung dan menyukseskan terbentuknya karakter moral yang baik maka berbagai Universitas di Indonesia menerapkan kebijakan dengan senantiasa melakukan pembaharuan standar proses termasuk di dalamnya pembelajaran di kelas. Setiap universitas selalu menampilkan ciri khas dari masing - masing. Pendidikan Pancasila dan Pendidikan Kewarganegaraan sendiri mempunyai peranan yang sangat penting dalam membentuk serta membangun jiwa nasionalis dan bermoral. Butir-butir yang terkandung dalam Pancasila mempunyai makna mendalam sebagai pedoman bagi seluruh rakyat Indonesia. 
Kemerosotan moral dan nilai kebangsaan dan ketahanan ideologi bisa dilihat dari hasil-hasil survei dan pengukuran (Latif, 2018). Untuk indeks ketahanan nasional sendiri, mengindikasi serta melemahkan ketahanan ideologi dan politik pada kurun tujuh tahun terakhir (2010 - 2016). Sedangkan indeks ketahanan ideologi (meliputi variabel toleransi, kesederajatan hukum, kesamaan hak dalam kehidupan sosial, dan persatuan bangsa mengalami kemrosotan pada skor 2.31 (pada 2010) menjadi 2.06 (pada 2016). Adapun hasil Survei Nilai - Nilai Kebangsaan (SNK) oleh BPS 2015 pertama kali survei di Indonesia. Setiap 100 orang Indonesia, diantaranya 18 orang bahkan tidak tahu judul lagu kebangsaan; selanjutnya 53 persen orang Indonesia tidak hafal sepenunya lirik lagu kebangsaan; sedangkan 24 orang dari setiap 100 orang Indonesia tidak hafal sila Pancasila; kemudian 42 persen orang Indonesia terbiasa memakai produk bajakan; diakhiri 55 Persen orang Indonesia jarang melaksanakan ikut kerja bakti.

Berdasarkan penjelasan tersebut, jelas ini sangat memprihatinkan. Karena Pancasila menjadi dasar negara yang mampu memberikan keteduhan kepada segenap warga bangsa dengan sila-silanya. Oleh karena itu, masa depan sebuah bangsa ditentukan oleh generasi-generasi muda. Baik buruknya suatu negara tentunya dapat dilihat dari kualitas pemudanya. Perlunya generasi muda untuk memiliki dan menumbuhkan rasa cinta tanah air serta tanggung jawab. Berperan aktif dan kritis serta solutif untuk bangsa dan negara serta mendukung sepenuhnya keberlangsungan penyelenggaraan negara.

Upaya-upaya yang terus dilakukan para mahasiswa sebagai generasi muda bangsa harus senantiasa menumbuhkan nilai-nilai Pancasila dan semangat kebangsaan yakni dengan cara mempelajari dan mempraktikkan Pendidikan Pancasila dan Pendidikan Kewarganegaraan dalam kehidupan bermasyarakat, berbangsa dan bernegara. Pemahaman wawasan kebangsaan juga diperlukan oleh para mahasiswa. Kemajuan dan kemunduran sebuah bangsa di masa mendatang ditentukan oleh sikap dan tindakan cakap, cerdas oleh para generasi muda. Apabila para generasi muda sudah tidak mementingkan atau acuh jiwa nasionalismenya maka masa depan bangsa akan semakin terpuruk. Oleh karena itu, memiliki serta memparaktikkan nilai-nilai kebangsaan merupakan hal yang sangat penting.

Berdasarkan latar belakang masalah tersebut, maka Pendidikan Pancasila dan Pendidikan Kewarganegaraan sangat penting sekali. Terutama untuk para mahasiswamahasiswa yang ada di Perguruan Tinggi untuk selalu mempelajari dan mengamalkan nilai-nilai Pancasila dan praktik kewarganegaraan dalam mengarungi kehidupan berbangsa dan bernegara. Oleh karena itu, penulis meneliti tentang pembelajaran Pendidikan Pancasila dan Pendidikan Kewarganegaraan di Perguruan Tinggi yang didasarkan pada fenomena-fenomena yang ada di Universitas Nusa Cendana, Universitas 
Tidar dan Universitas Muhammadiyah Purwokerto. Bagaimana strategi pembelajaran Pendidikan Pancasila dan Pendidikan Kewarganegaraan sebagai mata kuliah pembentuk karakter mahasiswa.

\section{TINJAUAN LITERATUR}

Pembelajaran

Penjelasan ini untuk menjelaskan tujuan utama pembelajaran Pendidikan Pancasila dan Pendidikan Kewarganegaraan di Perguruan Tinggi jug menjelaskan tuntutan pedagogis Pembelajaran Pendidikan Pancasila dan Pendidikan Kewarganegaraan tuntutan yang diinginkan oleh lembaga dalam memperoleh mata kuliah Pendidikan Pancasila dan Kewarganegaraan di Perguruan Tinggi. Dalam tulisan ini juga menjelaskan kemampuan yang seperti yang harus dimiliki mahasiswa dalam melakukan Pembelajaran di Perguruan Tinggi. Penulis juga menjelaskan strategi yang dapat dilakukan dalam pembelajaran Pendidikan Pancasila dan Pendidikan Kewarganegaraan di Perguruan Tinggi. Serta karakteristik mahasiswa yang harus dipahami dan dimengerti serta dilakukan mahasiswa agar menjadi warganegara yang baik.

Pembelajaran sangat dekat dengan strategi pembelajaran dari beberapa ahli mendefinisikan strategi, metode, pendekatan dan teknik pembelajaran antara lain sebagai berikut : (1) Strategi pembelajaran adalah seperangkat kebijaksanaan yang terpilih, yang telah dikaitkan dengan faktor yang menentukan warna atau strategi tersebut, yaitu : a) pemilihan materi pelajaran, b) penyaji materi pelajaran, c) cara menyajikan materi pelajaran, d)sasaran penerima materi pembelajaran. (2) Pendekatan pembelajaran adalah jalan atau arah yang ditempuh oleh guru atau siswa dalam mencapai tujuan pembelajaran dilihat bagaimana materi itu disajikan. (3) Metode pembelajaran adalah cara mengajar secara umum yang dapat diterapkan pada semua mata pelajaran, misalnya mengajar dengan metode ceramah, ekspositori, tanya jawab, penemuan terbimbing dan sebagainya. (4) Teknik mengajar adalah penerapan secara khusus atau metode pembelajaran yang telah disesuaikan dengan kemampuan dan kebiasaan dosen, ketersediaan media pembelajaran serta kesiapan mahasiswa, sehingga mahasiswa mendapatkan pembelajaran yang aktif serta menyenangkan (Nurdiansyah \& Fahyuni, 2016).

\section{Pendidikan Pancasila dan Kewarganegaraan}

Penjelasan ini mengungkapkan tentang mata kuliah Pendidikan Pancasila (semester ganjil) dan mata kuliah Pendidikan Kewarganegaraan (semester genap) yang diterapkan di Perguruan Tinggi. Penulis juga menjelaskan visi misi dari mata kuliah Pendidikan Pancasila dan Pendidikan Kewarganegaraan bagi mahasiswa. 
Pendidikan Pancasila adalah usaha sadar dan terencana untuk mewujudkan suasana belajar dan proses pembelajaran agar mahasiswa secara aktif mengembangkan potensi dirinya untuk memiliki pengetahuan, kepribadian, dan keahlian, sesuai dengan program studinya masing-masing. Dengan demikian, mahasiswa mampu memberikan kontribusi yang konstruktif dalam bermasyarakat, berbangsa, dan bernegara, dengan mengacu kepada nilai-nilai Pancasila. Visi Pendidikan Pancasila di Perguruan Tinggi adalah menjadi sumber nilai dan pedoman penyelenggaraan program studi dalam mengantarkan mahasiswa mengembangkan kepribadiannya selaku warga negara yang Pancasilais (Taniredja, 2019). Sedangkan misi Pendidikan Pancasila di Perguruan Tinggi adalah membantu mahasiswa agar mampu mewujudkan nilai-nilai dasar Pancasila serta kesadaran berbangsa, bernegara dalam menerapkan ilmunya secara bertanggung jawab terhadap kemanusiaan. Pembelajaran Pendidikan Pancasila yaitu pada akhir perkuliahan mahasiswa dapat memiliki pengetahuan dan memahami landasan dan tujuan Pendidikan Pancasila, Pancasila sebagai karya besar bangsa Indonesia yang setingkat dengan ideologi besar lainnya, Pancasila sebagai paradigma dalam kehidupan kekaryaan, kemasyarakatan, kebangsaan, dan kenegaraan, sehingga memperluas cakrawala pemikirannya, menumbuhkan sikap demokratis pada mereka dalam mengaktualisasikan nilai-nilai yang terkandung dalam Pancasila (Taniredja, 2019).

Pendidikan Kewarganegaraan dimaksudkan untuk membentuk peserta didik menjadi manusia yang memiliki rasa kebangsaan dan cinta tanah air (Kementerian Pendidikan dan Kebudayaan Indonesia, 2003). Pendidikan Kewarganegaraan (PKn) dirancang dengan maksud untuk memberikan pengertian kepada mahasiswa tentang pengetahuan dan kemampuan dasar berkenaaan dengan hubungan antar warga negara dengan negara serta pendidikan pendahuluan bela negara sebagai bekal agar menjadi warga negara yang dapat diandalkan oleh bangsa dan negara (Taniredja, 2019). Visi Pendidikan Kewarganegaraan yaitu menjadi sumber nilai dan pedoman dalam pengembangan dan penyelenggaran program studi guna mengantarkan mahasiswa memantapkan kepribadiannya sebagai manusia Indonesia seutuhnya. Misi Pendidikan Kewarganegaraan di Perguruan Tinggi adalah membantu mahasiswa selaku warga negara agar mampu mewujudkan nilai-nilai dasar perjuangan Bangsa Indonesia serta kesadaran berbangsa, bernegara dalam menerapkan ilmunyan secara bertanggung jawab terhadap kemanusiaan (Basrie, 2002).

\section{Penanaman Nilai-Nilai}

Pembelajaran Pendidikan Pancasila dan Pendidikan Kewarganegaraan memiliki misi yaitu penanaman nilai-nilai Pancasila seperti nilai-nilai dasar keagamaan dan 
kebudayaan, nilai demokratis rasa kebangsaan dan cinta tanah air sepanjang hayat dalam menguasai menerapkan dan mengembangkan pengetahuan teknologi dan seni yang dimilikinya dengan rasa tanggung jawab.

Tuntunan Pancasila sebagai pandangan hidup bagi bangsa Indonesia dalam bersikap dan bertingkah laku harus sesuai dengan nilai-nilai Pancasila sebagai berikut: (1) Sila Ketuhanan Yang Maha Esa, dikembangkan sikap toleransi antar umat beragama. (2) Sila Kemanusiaan yang Adil dan Beradab, dikembangkan dengan gemar melakukan menjunjung tinggi nilai-nilai kemanusiaan, kegiatan-kegiatan kemanusiaan, dan berani membela kebenaran dan keadilan. (3) Sila Persatuan Indonesia, dikembangkan atas dasar Bhinneka Tunggal Ika, dengan memajukan pergaulan demi persatuan dan kesatuan bangsa. (4) Sila Kerakyatan yang Dipimpin oleh Hikmat kebijaksanaan dalam Permusyawaratan Perwakilan, dikembangkan dengan musyawarah untuk mencapai mufakat ini diliputi oleh semangat kekeluargaan yang merupakan ciri khas bangsa Indonesia. (5) Sila Keadilan Sosial bagi Seluruh Rakyat Indonesia, dikembangkan dengan perbuatan luhur yang mencerminkan sikap dan perilaku dalam suasana kekeluargaan serta kegotongroyongan, sikap adil terhadap sesama, dan menjaga keseimbangan antara hak dan kewajiban (Taniredja, 2019).

Secara akademis Penanaman nilai dalam pembelajaran Pendidikan Pancasila dan Pendidikan Kewarganegaraan dapat didefinisikan sebagai suatu bidang kajian yang memusatkan telaahannya pada seluruh dimensi psikologis dan sosial budaya kewarganegaraan individu, dengan menggunakan ilmu politik, ilmu Pendidikan sebagai landasan kajiannya atauan penemuannya intinya yang diperkaya dengan disiplin ilmu lain yang relevan, dan mempunyai implikasi kebermanfatan terhadap instrumentasi dan praksis pendidikan setiap warga negara dalam konteks sistem pendidikan nasional (Winataputra, 2005).

Berdasarkan uraian di atas dapat dilihat bahwa betapa pentingnya peranan Pendidikan Pancasila dan Pendidikan Kewarganegaraan dalam mengembangkan pengetahuan, nilai, sikap, dan keterampilan sosial. Dengan pengembangan pembelajaran Pendidikan Pancasila dan Pendidikan Kewarganegaraan yang tepat maka dapat mengarahkan siswa menjadi warga masyarakat, bangsa dan negara Indonesia yang baik namun masih banyak ditemukan kelemahan dalam pembelajaran Pendidikan Pancasila dan Pendidikan Kewarganegaraan, baik dalam rancangan maupun proses pembelajaran. Untuk itulah betapa tantangan pembelajaran dan pengembangan model pembelajaran Pendidikan Pancasila dan Kewarganegaraan menjadi hal yang sangat penting untuk terus dikaji dan 
didiskusikan yang akhirnya mampu diimplementasikan seperti yang diharapkan. Walaupun pembelajaran Pendidikan Pancasila dan Pendidikan Kewarganegaraan sudah diberi "amanah lebih" untuk membentuk dan mengembangkan nilai dan moral pada peserta didik, tapi kenyataannya nilai dan moral itu lebih banyak terpatri pada asfek kognitif. Kurang tepatnya metode pengajaran dan pendekatan yang dipraktekkan di kelas selama proses pembelajaran menyumbangkan andil terbesar dari permasalahan ini, disamping juga diakibatkan karena sistem Pendidikan nasional, penyusunan kurikulum dan politisasi dalam dunia pendidikan dan sebagainya.

\section{Metode}

Jenis penelitian ini adalah deskriptif dengan pendekatan kualitatif. Moleong (2005), mengatakan bahwa penelitian kualitatif adalah jenis penelitian yang memfokuskan tentang apa yang dialami oleh subjek penelitian. Seperti prilaku, persepsi, motivasi, dan tindakan, digambarkan secara deskriptif melalui paparan kata-kata. Penelitian ini memfokuskan terhadap fenomena-fenomena atau sebuah kejadian. Pendekatan penelitian kualitatif yang dilakukan harus merujuk ketajaman analisis, objektivitas, sitematik dan ketepatan interperestasi dari peneliti yang dilakukan.

Metode penelitian bertujuan untuk mendapatkan data penelitian yang didasarkan bukti ilmiah yang kuat berdasar temuan hasil penelitian, (Sugiyono, 2012). Dengan ini, mengungkap gejala dan fenomena-fenomena terkait pembelajaran wajib PPKn di Perguruan Tinggi. Teknik pengumpulan data melalui wawancara, observasi, dokumentasi. Sedangkan Analisis data melalui reduksi data, penyajian data dan penarikan kesimpulan atau verifikasi.

\section{Hasil \& Diskusi}

Pentingnya mata kuliah Pendidikan Pancasila dan Pendidikan Kewarganegaraan sebagai mata kuliah umum wajb di Perguruan Tinggi terutang dalam Undang-undang Republik Indonesia nomor 12 tahun 2012 tentang Pendidikan Tinggi. Bahwa secara jelas menyebutkan terkait dengan kurikulum nasional setiap Perguruan Tinggi wajib memuat serta menyelenggarakan mata kuliah sebagai berikut yakni Pancasila, Kewarganegaraan, Agama dan Bahasa Indonesia. Undang-Undang No. 2 Tahun 1989 tentang Sistem Pendidikan Nasional, digunakan sebagai dasar dalam penyelenggaraan Pendidikan Tinggi. Dalam Pasal 39 ayat (2) disebutkan bahwa isi dari kurikulum setiap jenis, jalur, dan jenjang pendidikan wajib memuat: (a) Pendidikan Pancasila, (b) Pendidikan Agama, (c) 
Pendidikan Kewarganegaraan. Di dalam pelaksanaan operasionalnya bahwa ketiga mata kuliah wajib dari kurikulum tersebut terintegrasi dari kurikulum berlaku secara nasional.

Tidak bisa dipungkiri bahwa sejak tahun 1960 Pendidikan Kewarganegaraan (Civics) merupakan mata pelajaran wajib di semua jenjang pendidikan dari sekolah dasar sampai perguruan tinggi. Jadi, memang begitu sangat penting dan mempunyai peranan dalam membentuk peserta didik/mahasiswa yang paripurna, (Bunyamin Maftuh, 2008).

Sebelum dikeluarkannya Peraturan Pemerintah Nomor 60 Tahun 1999. Menteri Pendidikan dan Kebudayaan melalui Keputusan Nomor 30 Tahun 1990 telah menetapkan status bahwa mata kuliah pendidikan Pancasila dalam kurikulum pendidikan tinggi merupakan wajib untuk semua program studi serta bersifat nasional. Adapun silabus pendidikan Pancasila sendiri dari tahun 1983 sampai dengan tahun 1999, telah mengalami banyak perubahan untuk selalu menyesuaikan diri dengan perkembangan dan perubahan yang berlaku pada masyarakat, bangsa, dan negara yang bergitu cepat. Serta berbagai kebutuhan untuk selalu mengantisipasi perkembangan ilmu pengetahuan dan teknologi yang sangat masiv dengan tatanan kehidupan yang mengglobal.

Perubahan silabus Pancasila sendiri dikeluarkannya keputusan oleh Dirjen Dikti, Nomer. 265/Dikti/Kep/2000 mengenai penyempurnaan kurikulum inti yaitu mata kuliah pengembangan kepribadian pendidikan Pancasila di perguruan tinggi Indonesia. Keputusan ini dinyatakan bahwa pendidikan Pancasila sebagai mata kuliah yang mencakup unsur filsafat pancasila. Di mana salah satu komponen yang tidak bisa dipisahkan dengan kelompok mata kuliah pengembangan kepribadian (MKPK). Dalam susunan kurikulum inti di perguruan tinggi mata kuliah pendidikan pancasila sebagai mata kuliah wajib yang harus diambil oleh mahasiswa pada perguruan tinggi untuk semua jenjang seperti diploma/politeknik dan program sarjana. Pendidikan pancasila sendiri dirancang dengan tujuan dan maksud untuk memberikan pemahaman dan pengertian kepada para mahasiswa tentang pancasila sebagai tata nilai norma, nilai bangsa, dasar negara, dan ideologi nasional.

Tujuan Pendidikan Pancasila di Perguruan Tinggi secara akademik sendiri diharapkan mampu memberikan pembelajaran aktif bagi para mahasiswa untuk mengkaji, menganalisis, dan memecahkan persoalan bangsa dan negara. Dalam perspektif nilai-nilai dasar Pancasila adalah sebagai ideologi serta dasar negara Indonesia. Pendidikan Pancasila bertujuan untuk mewujudkan tujuan cita-cita Pendidikan Nasional. Sistem pendidikan nasional sendiri adalah rangkaian konsep, tata cara, program dan usaha untuk mewujudkan tujuan nasional. Hal ini yang telah diamanatkan Undang-Undang Dasar Tahun 1945, yakni ikut mencerdaskan kehidupan bangsa. Jadi, tujuan dilaksanakan 
pendidikan Pancasila di semua jenjang, jurusan yang ada di perguruan tinggi merupakan salah satu upaya untuk mencerdaskan kehidupan bangsa.

Pendidikan Pancasila dan Pendidikan Kewarganegaraan merupakan mata kuliah wajib umum (MKWU) yang diberikan kepada seluruh mahasiswa di Universitas Nusa Cendana, Universitas Tidar dan Universitas Muhammadiyah Purwokerto. Pendidikan Pancasila dan Pendidikan Kewarganegaraan masing -masing berbobot 2 sks yang diampu oleh dosen pengampu lintas prodi dengan harapan interaksi satu sama lain dalam menghayati moral Pancasila maupun kajian hak dan kewajiban Warga Negara yang melahirkan rasa kecintaan terhadap tanah air Indoensia dalam kehidupan bermasyarakat, berbangsa dan bernegara. Pendidikan Pancasila biasanya diajarkan pada semester 1 bagi mahasiswa baru dalam bentuk mata kuliah 2 sks untuk 16 kali pertemuan, sedangkan mata kuliah pendidikan kewarganegaraan diajarkan pada semester genap atau 4 dengan bobot yang sama 2 SKS.

Pancasila merupakan dasar filsafat negara Indonesia, hal ini tercantum dalam pembukaan Undang-Undang Dasar 1945. Oleh karena itu, bagi setiap warga negara Indonesia harus mendalami, mempelajari, menghayati, dan bisa mengamalkan dalam kehidupan berbangsa dan bernegara. Pancasila menjadi warisan yang sangat agung dari para founding fathers yang mengacu pada nilai-nilai luhur budaya bangsa. Nilai luhur tersebut menjadi sebuah panutan hidup yang telah hilang otoritasnya. Dengan demikian, manusia menjadi menjadi bingung. Dari berbagai macam kebingungan tersebut bisa menimbulkan krisis-krisis yang nantinya akan berdampak pada bidang politik, ekonomi, sosial budaya, serta pertahanan dan keamanan. Selain itu, juga berpengaruh terhadap moral dan sikap perilaku manusia.

Proses pembelajaran yang berpusat pada mahasiswa, dilaksanakan dengan mengadakan tahapan perencanan, pelaksanaan dan evaluasi senantiasa disesuaikan dengan perkembangan zaman, proses pembelajaran dikelas diadakan dengan membagi mahasiswa menjadi 13 kelompok diskusi, yang berkewajiban mempresentasikan pokokpokok materi seputar Pendidikan Pancasila dan diulas dalam diskusi kelas yang didampingi dosen mata kuliah Pendidikan Pancasila dan Pendidikan Kewarganegaraan. Tugas-tugas lain yang diberikan adalah tugas yang berbasis masalah sosial seputar wilayah NTT maupun nasional dan kearifan local yang menyangkut moral Pancasila, biasanya tugas tersebut didiskusi dan dibahas bersama di dalam kelas. Di Untidar sendiri selain mendapatkan materi juga ada tugas kelompok serta diskusi-diskusi fenomena terkini dan transfer values knowledge serta menjunjung tinggi nilai-nilai kearifan lokal dan sosial berdasarkan Pancasila. 
Mahasiswa lebih tertarik akan kausalitas masalah-masalah sosial yang di telaah berdasarkan moral Pancasila dan dibuktikan dalam dialog yang alot dalam membedah kasus-kasus tersebut, keterlibatan mahasiswa dalam pembelajaran Pendidikan Pancasila dan Pendidikan Kewarganaraan didapatkan dengan melihat kehadiran mahasiswa dalam mengikuti perkuliahan yang signifikan 80-90 persen kelas, maupun partisipasi dalam menyampaikan pendapat saat proses perkuliahan Pendidikan Pancasila dan Pendidikan Kewarganegaraan serta kreatifitas dan keterampilan dalam menyiapkan power point yang disajikan di kelas. Pengembangan karakter dalam pendidikan Pancasila lebih mengarah kepada pengetahuan moral mahasiswa akan apa yang benar dan seharusnya dilakukan, mengenai penerapan perilaku selanjutnya perlu kerja keras segenap elemen bangsa dalam menciptakan iklim pembudayaan Pancasila sehingga pengetahuan moral Pancasila yang didapatkan tetap terpelihara dan menjadi acuan berkehidupan bermasyarakat, berbangsa, dan bernegara.

Pembelajaran Pendidikan Pancasila dan Pendidikan Kewarganegaraan yang menerapkan kesepakatan bersama melalui musyawarah akan kontrak kuliah menumbuhkan karakter-karakter yang mencerminkan nilai-nilai Pancasila seperti memulai dan mengakhiri perkuliahan dengan berdoa, ketidakhadiran maksimal 20 persen dari 16 kali pertemuan mencirikan tanggungjawab dan disiplin, kedisiplinan dalam waktu perkuliahan maupun pengumpulan tugas, mengutamakan musyawarah dalam memecahkan masalah, tidak membedakan suku, agama, ras, golongan dalam mengemukakan pendapat maupun berbagai kegiatan. Dalam hal ini didasarkan beragamnya mahasiswa maupun dosen Universitas Nusa Cendana yang berlatar belakang dari kepualauan NTT yakni dari pulau Timor, pulau Flores, pulau Alor, pulau Lembata, pulau Solor dan sekiatrnya, pulau Rote, pulau Sabu, dan Pulau Sumba serta kepualauan lainnya, selain itu keanekaragaman juga karena adanya mahasiswa maupun dosen yang berasal dari Jawa, Sulawesi, Sumatra, Papua, dan lain-lain. Standar penilaian jelas seperti termuat dalam RPS yang diberikan pada awal perkuliahan, hal ini mencerminkan keadilan yang merata. Aktualisasi kebhinekaan perlu digaungkan di perguruan tinggi sebagai dasar menghargai keragaman, (Hakim et al., 2020).

Pembelajaran Pendidikan Pancasila dan Pendidikan Kewarganegaraan di Universitas Tidar masing-masing ada 16 kali pertemuan maisng-masing dengan bobot 2 SKS yang mana di Magelang Jawa Tengah adalah kultur religious, nasionalisme, budaya, dan pendidikan. Banyaknya pesantren serta ada pendidikan militer, banyak budaya seperti tari soreng, ada banyak candi dan banyak berdiri sekolah formal, non formal dan informal. Hal ini menunjukkan harmoni dan sinergitas antar komponen serta lingkungan yang mendukung dalam upaya teori dan praktik bersumber pada nilai-nilai Pancasila. Dengan 
demikian mahasiswa ditempa selain teori dan materi perkuliahan adalah dengan ikut serta mempelajari dan beradaptasi di lingkungan yang mendukung suasana dalam perkuliahan terutama praktik kewarganegaraan.

Sedangkan di Universitas Muhammadiyah Purwokerto yang merupakan Perguruan Tinggi dengan basic Muhammadiyah dan keIslaman yang memiliki Kultur religious, toleransi, demokratis dan nasionalisme yang diimplementasikan dalam Pembelajaran Pendidikan Pancasila dan Pendidikan Kewarganegaraan. Pembelajaran Pendidikan Pancasila dan Pendidikan Kewarganegaraan di Universitas Muhammadiyah Purwokerto dengan menerapkan model pembelajaran seperti Problem Based Learning dan Project Citizen yang diharapkan membentuk sikap toleransi, demokratis dan nasionalisme mahasiswa. Kedua model pembelajaran tersebut menjadikan mahasiswa kritis terhadap permasalahan yang terjadi di lingkungan sekitarnya pada khususnya dan di Indonesia pada umumnya. Sikap kritis ini menunjukkan kepedulian dari mahasiswa untuk memberikan solusi terhadap permasalahan-permasalahan di Negara Indonesia sehingga diharapkan dapat membentuk sikap nasionalisme yang bersumber pada nilai-nilai Pancasila. Dengan demikian, mahasiswa selain diberikan materi perkuliahan secara teoretis juga menjalankan praktik kewarganegaraan yaitu menjalankan hak dan kewajibannya sebagai warga Negara.

Kesadaran kecintaan Pancasila selain di kelas dalam prakteknya, nampak dalam seremonial kegiatan di kampus. Kegiatan yang diadakan Universitas Cendana, Universitas Tidar maupun Universitas Muhammadiyah Purwokerto baik itu organisasi mahasiswa selalu mengawali dengan berdoa dan menyanyikan lagu kebangsaan Indonesia Raya, pengambilan keputusan oleh ormawa maupun pihak civitas akademika mengedepankan musyawarah untuk mufakat. Dalam kegaiatan resmi maupun dikelas civitas akademika undana selalu memakai salam nasional maupun salam keagamaan dari agama di Indoensia, menyadarkan akan keberagaman dalam bingkai Bhineka Tunggal Ika di jiwai nilai - nilai luhur Pancasila.

Mata kuliah Pendidikan Pancasila dan Pendidikan Kewarganegaraan sebagai mata kuliah wajib umum dalam mengembangkan kepribadian mahasiswa yang dilaksanakan di Universitas Nusa Cendana, Universitas Tidar dan Universitas Muhammadiyah Purwokerto. Dalam hal ini mengacu kepada ketentuan yang berlaku seperti UU No 12 Tahun 2012 tentang Pendidikan Tinggi maupun Standar Nasional Pendidikan Tinggi. Tentunya Pendidikan Pancasila dan Pendidikan Kewarganegaraan mempunyai sasaran kompetensi yang memiliki peran mengembangan kepribadian mahasiswa. Mata kuliah Pendidikan Pancasila dan Pendidikan Kewarganegaraan mempersiapkan dengan langkah dimulai dari tahap perencanaan. Tahap perencanaan ini dosen Pendidikan Pancasila dan Pendidikan 
Kewarganegaraan mempersipakan perkliahan seperti kontrak perkuliahan dan rencana pembelajaran semester (RPS). Langkah berikutnya adalah tahap perencanaan yaitu tahap pelaksanaan, dalam pelaksanaan ini sendiri mengacu pada langkah yang pertama yaitu perencaaan. Adapun pelaksanaannya mengacu pada rencana pembelajaran semester (RPS) yang telah dibuat. Tahap terakhir adalah evaluasi, tahap evaluasi ini dilakukan dan disesuaikan dengan ketentuan yang berlaku. Yakni sesuai dengan istrumen-instrumen dan bobot penelitian yang ada dalam rencana pembelajaran semester yang dibuat.

Berdasarkan hal tersebut, maka rencana pembelajaran semester (RPS) adalah bagian administrasi yang menjadi acuan, terutama dalam perkuliahan untuk mendapatkan sasaran capaian pembelajaran. Selanjutnya capaian pembelajaran selalu menekankan pada tiga aspek atau ranah capaian pembelajaran, pertama adalah capaian pengetahuan, kedua adalah capaian keterampilan, dan ketiga adalah capaian sikap.

\section{Kesimpulan}

Berdasarkan penelitian yang telah dilakukan di Universitas Nusa Cendana, Univeritas Tidar dan Universitas Muhammadiyah Purwokerto dapat diambil kesimpulan bahwa peran mata mata kuliah Pendidikan Pancasila dan Pendidikan Kewarganegaraan sebagai mata kuliah wajib umum yang membentuk karakter mahasiswa. Kemudian Pendidikan Pancasila dan Pendidikan Kewarganegaraan juga mengembangkan kepribadian para mahasiswa sesuai dengan nilai-nilai Pancasila sudah berjalan dengan baik. Hal ini, dalam kegiatan perkuliahan mengedepankan kualitas pembelajaran. Untuk dapat mencapai kualitas perkuliahan dilakukan dengan tiga tahap, pertama yaitu tahap perencanaan, kedua tahap pelaksanaan, dan ketiga tahap evaluasi. Semuanya itu bertujuan demi mencapai capaian pembelajaran atau perkuliahan yang baik. Adapun capaian tersebut meliputi capaian pengetahuan, capaian keterampilan dan capaian sikap. Kemudian capaian pengetahuan adalah suatu sasaran yang tentunya ingin dicapai dalam ranah kompetensi kognitif. Kompetensi pengetahuan pada mahasiswa diajarkan meteri yang ada dalam rencana pembelajaran semester (RPS).

Tujuan tersebut mahasiswa dapat mengetahui dan memahami tentang hakikat Pancasila. Capaian selanjutnya yaitu capaian keterampilan, dalam capaian keterampilan mahasiswa dituntut untuk dapat terampil sebagai langkah dari capaian pengetahuan. Adapun capaian keterampilan ini dilakukan melalui proses perkuliahan yang berpusat pada mahasiswa atau student centered learning. Di dalam perkuliahan, mahasiswa dilatih untuk bisa terampil mempraktikkan pengetahuan yang sudah didapatnya. Keterampilan ini diterapkan melalui metode-metode, seperti ceramah, presentasi, studi kasus, diskusi, debat, dan observasi lapangan. Metode tersebut diterapkan dalam proses belajar dan 
pembelajaran di bangku kuliah yang bertujuan untuk dapat mencapai capaian keterampilan mahasiswa.

\section{Referensi}

Basrie. (2002). Modul Acuan Proses Pembelajaran Mata Kuliah Pengembangan Kepribadian Pendidikan Kewarganegaraan. Jakarta : Departemen Pendidikan Nasional Direktorat Jenderal Pendidikan Tinggi.

Bunyamin Maftuh. (2008). Internalisasi Nilai-Nilai Pancasila dan Nasionalisme Melalui Pendidikan Kewarganegaraan. Educationist, II(2), 134-144.

Hakim, S., Mulyani, M., Mazid, S., \& Fitriana, R. (2020). Aktualisasi Kebinekaan Era New Normal di Lingkungan Pendidikan Tinggi. Jurnal Kalacakra, 01, 32-40.

Hamidah. (2019). Implementasi Pendidikan Kewarganegaraan di Perguruan Tinggi. Forum Pedagogik, 11.

Kaelan, A., \& Zubaidi. (2007). Pendidikan Kewarganegaraan untuk Perguruan Tinggi. Yogyakarta : Paradigma.

Kementerian Pendidikan dan Kebudayaan Indonesia. (2003). Undang-Undang Republik Indonesia Nomor 20 Tahun 2003 Tentang Sistem Pendidikan Nasional.

Latif, Y. (2018). Wawasan Pancasila: Bintang Penuntun Untuk Pembudayaan. Jakarta : Mizan.

Mazid, S., \& Suharno, S. (2019). Implementasi nilai-nilai multikultural dalam pembelajaran pendidikan kewarganegaraan. Harmoni Sosial: Jurnal Pendidikan IPS, 6(1), 72-85.

Moleong, L. J. (2005). Metodologi Penelitian Kualitatif. Bandung : Remaja Rosda Karya.

Nurdiansyah, \& Fahyuni, E. F. (2016). Inovasi Model Pembelajaran. Sidoarjo : Nizamia Learning Centre.

Sugiyono. (2012). Metode Penelitian Kuantitatif Kualitatif dan R\&D. Bandung : Alfabeta.

Syahrial Syarbaini, M.A. (2012). Pendidikan Pancasila Implementasi Nilai-Nilai Karakter Bangsa. Bogor. Ghalia Indonesia

Taniredja, T. (2019). Paradigma Terbaru Pendidikan Kewarnegaraan untuk Mahasiswa. Bandung : Alfabeta.

Ulfa, R. A., Prasetyo, D., \& Marzuki, M. (2018). Pengaruh Model PBM dalam Pembelajaran PPKn terhadap Kemampuan Berpikir Kritis dan Sikap Demokratis. Citizenship Jurnal Pancasila dan Kewarganegaraan, 6(2), 125-139.

Winataputra, U. S. (2005). Pendidikan Kewarganegaraan untuk Membangun Masyarakat Berdemokratis dan Berkeadaban. Makalah Seminar Lokakarya Dosen Pendidikan Kewarganegaraan PTN dan PTS. 